\title{
Money and the English Economy in the Twelfth and Thirteenth Centuries
}

\author{
Paul Latimer*
}

Department of History, Bilkent University

\begin{abstract}
The subject of money is of clear importance to the history of the English economy in the twelfth and thirteenth centuries and has attracted a considerable literature over the past decades. The author surveys the main strands of this work, dealing with the coinage itself, its production and quantity, its distribution and use, whether money can be equated with the coinage, and the question of credit. The article then goes on to deal with the debates on two important issues involving money in the period, the questions of inflation and commercialization, and suggests ways in which they should be taken forward.
\end{abstract}

Few historians would deny that money was important in the medieval economy. Although no one doubts that, throughout the Middle Ages and beyond, much subsistence production and consumption took place without directly requiring money, the days are long gone when even the early medieval economy could be regarded as a "natural economy', much less that of England in the twelfth and thirteenth centuries. ${ }^{1}$ This was a period in England during which undoubtedly both the quantity and the use of money increased substantially in its then predominant form of a silver-based coinage. This coinage is of intrinsic interest to historians and numismatists as a cultural artifact, irrespective of the importance of its economic role, but to one degree or another scholars have generally acknowledged its economic significance, though often disagreeing on its importance as an explanatory factor in particular economic developments.

Before turning to questions about the relationship of money to the economy, principally its impact in determining prices and its role in commercialization, it seems best to start with the coinage itself, its production and its quantity. It was in many ways an exceptional coinage in European terms. A single category of coins, a relatively high-value silver penny of a generally consistent standard, dominated the English currency to an exceptional degree. ${ }^{2}$ The surviving physical evidence of the coins and its analysis, whether it concerns coin hoards or single-finds, are continuously being augmented, albeit usually in small increments of varying significance. The only practical way to follow this is to keep an eye on the dedicated numismatic journals, notably the British Numismatic Journal and the Numismatic Chronicle. ${ }^{3}$ On the other hand, the outline of the changes in the way coin production was organized in England has by now long been clear and is unlikely to change very much. An Anglo-Saxon system of numerous regional mints and frequent recoinages that was inherited by Henry I was transformed into a system where, except during recoinages that were to become relatively rare events, the London mint, sometimes supplemented by Canterbury, dominated the minting of coins. Although there are many complexities to the story, the core of this transformation lay in the reorganization Henry II made for the 1180-1182 recoinage. ${ }^{4}$ One can find recent work on the fate of the families of moneyers, those who produced the coins under the earlier system; on 
thirteenth-century mint and exchange officials; on thirteenth-century ecclesiastical mints, and other individual mints. There is, however, little here that will radically change the overall picture. ${ }^{5}$ It is also probably in view of the quality of earlier work that there seems to have been rather a dearth of recent publications specifically on the second half of the thirteenth century, a period relatively rich in records. One suspects, however, that this recent relative neglect will change at some point. ${ }^{6}$

Considerable effort and ingenuity has been put into trying to establish the quantity of the English coinage in the period, an intricate and problematic task. This is especially so before records of mint output start to become available in the 1220s. Even then there is the problem that these do not cover all the mints in operation, particularly at times of recoinage, which in turn represent the best opportunity for trying to calculate the quantity of the existing coinage, as opposed to the number of coins being minted each year. Before mint records become available, we are reliant on calculations based on the number of dies and estimates of the number of coins they can be expected to have produced. However, these estimates can only be made from evidence of the later period for which we do have mint records. ${ }^{7}$ Nevertheless, a fair measure of agreement has been reached on the trajectory of the growth in the quantity of the coinage. A spectacular, if perhaps uneven, growth in the quantity of coinage in the period from 1180 to 1205, probably already starting in the decades before 1180, was followed by further, perhaps slower growth, which accelerated again in the last two decades of the thirteenth century. While many obscurities remain, especially concerning the first half of the twelfth century, it seems almost certain that the quantity of the coinage in 1300 was more than ten times that of 1158 or before. ${ }^{8}$ By far the most important source of this growth has recently been reaffirmed to be silver imported from abroad through trade, especially the wool trade. $^{9}$

One problem with estimates based, one way or another, on the production of English silver coins is that the minting of a coin in England did not guarantee that it stayed in England. While we know something of large political transfers of English money out of the country, which were certainly capable of making a significant impact on the quantity of the coinage in England, transfers of English coins both in and out of the country by commerce are difficult to quantify, as also are the English coins that left England to circulate outside of England. This in turn led to the circulation of Continental imitations of English coins that, in the form of 'crockards and pollards' in the late thirteenth century, came to England to form a not inconsiderable part of the currency, though at least this latter problem is to a reasonable extent quantifiable. ${ }^{10}$ To complicate matters a little further, there were always some foreign gold coins in England. ${ }^{11}$ While it would be surprising if further progress on these problems were radically to change our view on the quantity of the coinage in England, refinements in that view will no doubt continue.

It is necessary to stress though that estimates of aggregate quantities of the coinage at different times, however, judicious or precise - and they cannot be very precise-can only take us so far when we start to consider the role of money in the economy. There are some questions we need to think about before we can approach topics such as the relationship between money and prices or the subject of commercialization. How was the coinage distributed and how was it used, or not used? To what extent can we equate the silver coinage with money, and how should we regard the role of credit?

Given a particular quantity of coinage in the country at a particular time, one would expect its economic impact to depend in part at least on how it is distributed. As James Bolton justifiably suggested, the situation where King John in the early thirteenth century held a not inconsiderable part of the English coinage in his treasuries for some years 
would likely have had a depressing effect on the economy. ${ }^{12}$ Although this was perhaps an extreme case of uneven distribution, it was far from the only case where kings accumulated substantial cash reserves for a period. At all levels of society though, we would like to know more about who held coins, especially coins that were not always immediately destined for exchange. If we follow Nicholas Mayhew's logic, one of the effects of the increasing quantity of the coinage was to allow people on average to hold more coins for longer, the coinage having to work less frantically in 1300 than it had had to do in 1086, even though there were at the same time more uses for coins in an economy that was increasingly monetized. ${ }^{13}$ However, again, aggregates can only tell us so much; figures such as estimates of the number of coins per capita conceal a highly uneven distribution, and what people did with their coins and when they would spend them would depend very much on their station in life. While information for the twelfth and thirteenth century is relatively sparse and scattered, potential sources in the form of such records as inquisitions post mortem, wills and accounts of legal cases do exist with which to investigate holdings of coin, albeit the result of such an investigation could hardly hope to be more than impressionistic.

Broadly speaking, it seems relatively straightforward to describe what money was in twelfth- and thirteenth-century England. While there were some foreign gold coins, they were few, which also seems to have been the case for any kind of 'black money', tokens or jettons at this time. Uncoined silver, in one form or another, might sometimes be used like money, but this does not seem to have been common enough to worry about. Also, while money could be created by means of negotiable financial instruments of one kind or another, this possibility too seems to have been rather rarely used at this time. ${ }^{14}$ It is usually accepted that there was relatively little money apart from that represented by the English silver coinage.

Credit on the other hand was a crucial part of the functioning of the economy, both in the form of advances from existing cash balances and through postponement of payment, though as Mayhew has argued, both of these should be seen as enabling the existing coinage to try to cope with the demands of the economy, rather than as adding to the money supply. ${ }^{15}$ The subject of credit, both involving the Jews and otherwise, has deservedly generated a considerable recent literature, and is likely to continue to do so, although by and large this work has concerned the legal framework of money-lending and the role of credit in the lives of groups and individuals, emphases that are largely dictated by the available sources, rather than being concerned with aggregate amounts of credit. $^{16}$ We can, to some extent, build up an impression of the commonness of credit transactions, but it is difficult to see how it can be quantified for most of the period here in question. ${ }^{17}$ It is to be hoped also that, sources permitting for this period, renewed attention can be given to the question of credit sales, something that has been relatively neglected.

It is not very surprising that modern inflationary worries, particularly from the late 1960s to the early 1980s, and the concurrent, often ideological, debates over monetarism, should stimulate interest from historians, and others concerned with historical economics, in past periods of relatively rapid price rises and in the role of the quantity of money in those price rises. One early focus of such interest was in the 'Price Revolution' of the sixteenth century and many of the arguments here would go on to have a considerable impact on the parallel discussion concerning medieval prices, most importantly for us here, prices in the twelfth and thirteenth centuries. ${ }^{18}$ Arguments about these were already bubbling up at the time of Michael Postan's Medieval Economy and Society in 1972. Although he did not completely disregard the possible importance of monetary factors in 
price and wage changes, he tended to see their effect as relatively minor and championed demographic factors as much more important. ${ }^{19}$

It was, however, Paul Harvey's 1973 article that shaped the argument to come. ${ }^{20}$ Harvey's argument was that price increases in the period from 1180 to 1220 stood out from other price changes in the twelfth and thirteenth century, and that they resulted from an increase in the quantity of the coinage, in turn made possible by English exports, chiefly of wool, that brought in a flood of silver. It was this 'monetarist' view that was to set the tone of the argument to come, which would often range wider than the period Harvey had been concerned with, and which would stimulate much of the work on the quantity of the coinage that we have looked at above.

Reactions to Harvey's argument from Miller and Hatcher, Bolton and Mayhew ranged from defence of the older demographic explanation of price rises, to some degree modified by conceding some role to the quantity of money ${ }^{21}$ - after all Postan had already done that to a degree - to support on a wider scale for the importance of the quantity of money in explaining prices. ${ }^{22}$ There was also an argument from Palmer that posited changes in the velocity of money on the basis of changes in land law as significant, ${ }^{23}$ as well as contributions from Bridbury, Farmer and Bolton that might be characterized as skeptical of all these arguments. ${ }^{24}$

Harvey's periodization of the price rises was then contested by Latimer, who argued instead for a concentrated period of price rises in the very early years of the thirteenth century, also attempting to extend the range of prices that could be considered. The implications of this then led on to a re-examination of the changes in the quantity of money in the period, as well as of the rise in wages, important in countering the demographic explanation for rising prices. Latimer concluded with an argument that the sharp rise in prices was due to a collapse in the desire to hold money because of doubts about the state of the currency, especially just prior to the 1205 partial recoinage, and that the desire to hold money could not recover in the short term because of the threat from royal taxation of moveables. ${ }^{25}$

In more recent years, although work on refining our picture of the quantity of the coinage, as we have seen, has continued, the arguments about inflation in the twelfth and thirteenth century have rather receded. This is perhaps partly because of less inflationary times in the contemporary world, perhaps also because, amongst economists as well as historians, faith in the more mechanistic kind of relationship between money and prices has diminished. ${ }^{26}$ Yet there is still work to be done, particularly perhaps concerning prices for the second half of the thirteenth century where the sources are potentially most forthcoming.

David Farmer's 1988 account of prices and wages has proved immensely useful and stimulating to discussion. Together with Farmer's earlier work and Lloyd's survey of wool prices, it has come to form the basis of historians' picture of prices in general from the second half of the twelfth century to the mid fourteenth century. ${ }^{27}$ Yet this picture has its weaknesses, as David Bachrach has recently detailed while looking into the interesting area of the prices paid by royal officers for requisitioned goods in Edward I's reign. ${ }^{28}$ Also, while crops, livestock and wool are clearly extremely important commodities, they are a rather limited set of prices from which to get a full picture of prices in the thirteenth-century economy, particularly so perhaps as that century wore on. If we are to try to form as full a picture of the thirteenth-century economy as possible, and of money's role in it, then more work on prices is both necessary and possible.

A fairly recent article by James Bolton, after discussing the nature of money and of a money economy, concluded that indeed England represented a money economy by the 
end of the thirteenth century. ${ }^{29}$ Questions about monetization and commercialization have throughout formed an important part of the discussion of money and the economy in the twelfth and thirteenth centuries. While the two concepts are clearly closely connected and overlap, the difference is perhaps that whereas monetization is concerned, strictly speaking, simply with the extent of the use of money in the economy, commercialization should properly include the way in which the incentive and ability to trade, often through markets of one kind or another and no doubt facilitated by money, alters economic behavior. Twin landmarks in the study of these intimately related subjects were Britnell's 1993 book on commercialization and the 1995 collection of essays edited by Britnell and Campbell. ${ }^{30}$ No one would, I think, doubt Britnell's conclusion that England was more commercialized in 1300 than it had been in 1000, or for that matter that England had become more monetized, or that markets and fairs were important in the process. Questions though over what drove the process-population growth, urban growth in particular, the greater availability of money, the burgeoning of markets, or even, to a degree, landlords' and others' reactions to price movements, ${ }^{31}$ or all of these in some measure-produce such a set interrelated problems as to challenge historians indefinitely and almost to defy theorizing.

Money's role in the process of commercialization is clear enough as an important facilitator, less clear as a driving force. ${ }^{32}$ The future for historical work on this topic would seem to lie, not so much in producing a new theory of the causes of commercialization involving money, but in the gradual building up of a more complete and nuanced picture of the development of money's role in society and the economy. The study of that role and of commercialization itself, as Britnell has recently emphasized in respect of rural trade, also needs to be seen as dealing with particular aspects of a more holistic research agenda for economic history, one that considers a diverse range of processes and pressures bringing about change in the medieval economy. ${ }^{33}$

\section{Short Biography}

Paul Latimer is Assistant Professor at the Department of History, Bilkent University in Ankara, Turkey and has a B.A. and Ph.D. from the University of Sheffield (1982). His work has focused on a variety of economic, social and political matters concerning twelfth- and thirteenth-century Britain, with journal articles published in Historical Research, Welsh Historical Review, The Haskins Society Journal, the Journal of European Economic History, Past and Present, Albion and Northern History.

\footnotetext{
Notes

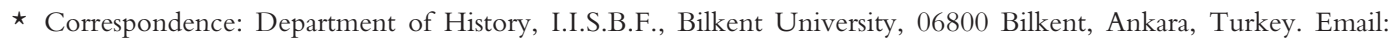
paul@bilkent.edu.tr.

1 In the early twentieth century, Henri Pirenne considered the term 'natural economy' with reference to the early Middle Ages, but stressed that it could only be used as a relative term: H. Pirenne, An Economic and Social History of Medieval Europe, transl. I. E. Glegg (London: Routledge, 1936), 103-5.

2 The best overview of European coinages in the Middle Ages is still P. Spufford, Money and Its Use in Medieval Europe (Cambridge: Cambridge University Press, 1988).

3 There are also useful internet-based coin databases such as The Portable Antiquities Scheme, Medieval Coin Guide, http://finds.org.uk/medievalcoins, accessed on 9 Dec, 2010, and the Fitzwilliam Museum's Early Medieval Corpus: Single Finds of Coins in the British Isles, 410-1180, http://www-cm.fitzmuseum.cam.ac.uk/emc/emc_intro.html, accessed on 9 Dec, 2010.
} 
4 The overall picture is perhaps still best approached through I. Stewart, 'The English and Norman Mints, c. 6001158' in C. E. Challis (ed.), A New History of the Royal Mint (Cambridge: Cambridge University Press, 1992), 1-82 and N. J. Mayhew, 'From Regional to Central Minting, 1158-1464' in ibid., 83-178. See also, J. D. Brand, The English Coinage 1180-1247: Money, Mints and Exchanges (Stroud: Sutton, 1994) and G. Stack, 'A Lost Law of Henry II: The Assize of Oxford and Monetary Reform', Haskins Society Journal, 16 (2006 for 2005): 95-103. The most recent and most comprehensive account of the decisive period in this transformation is M. R. Allen, 'Henry II and the English Coinage' in C. Harper-Bill and N. Vincent (eds.), Henry II: New Interpretations (Woodbridge: Boydell, 2007), 257-77.

5 See, for example, D. J. Symons, 'The Moneyers of the Worcester Mint, 1066-1158: Some Thoughts and Comments' in B. J. Cook and G. Williams (eds.), Coinage and History in the North Sea World, c. AD 500-1250: Essays in Honour of Maroin Archibald (Leiden: Brill, 2006), 545-88; M. R. Allen, 'Salaries of Mint and Exchange Officials in the Long Cross Recoinage of 1247-50', British Numismatic Journal, 75 (2005): 173-75; M. R. Allen, 'Ecclesiastical Mints in Thirteenth Century England', in M. Prestwich, R. H. Britnell and R. Frame (eds.), Thirteenth Century England VIII, Proceedings of the Durham Conference, 1999 (Woodbridge: Boydell, 2001), 97-122; J. Eaglen, The Abbey and Mint of Bury St Edmunds to 1279, British Numismatic Society special publication, 5 (London: Spink, 2006); W. N. Clark and D. Symons, 'The Mint of Aylesbury', British Numismatic Journal, 77 (2007): 173-89.

6 N. J. Mayhew (ed.), Edwardian Monetary Affairs (1279-1344), British Archaeological Reports, 36 (Oxford: British Archaeological reports, 1977) was indeed a sparkling collection of work. For some examples of the rather sparse more recent writing on this period, see N. J. Mayhew, 'Irregularities in the Irish Mint Accounts 1279-84', in N. J. Mayhew and P. Spufford (eds.), Later Medieval Mints: Organisation, Administration and Techniques: The Eighth Oxford Symposium on Coinage and Monetary History, British Archaeological Reports, International Series, 389 (Oxford: British Archaeological Reports, 1988), 87-96; M. R. Allen, 'The Groats of Edward I', British Numismatic Journal, 74 (2004): 28-38.

M. R. Allen, 'Medieval English Die-Output', British Numismatic Journal, 74 (2004): 29-49.

8 D. M. Metcalf, 'A Survey of Research into the Pennies of the First Three Edwards (1279-1344) and Their Continental Imitations', in Mayhew (ed.), Edwardian Monetary Affairs (1279-1344), 1-31; N. J. Mayhew, 'Money and Prices in England from Henry II to Edward III', Agricultural History Review, 35 (1987): 121-32; M. R. Allen, 'The Volume of the English Currency, 1158-1470', Economic History Review, New Series, 54 (2001): 595-611; P. Latimer, 'The Quantity of Money in England 1180-1247: A Model', Journal of European Economic History, 32 (2003): 637-59; M. R. Allen, 'The Quantity of Money in England 1180-1247: New Data', British Numismatic Journal, 75 (2005): 44-9; Allen, 'Henry II and the English Coinage', 272-5. Martin Allen's latest figures, taken from M. R. Allen, Mints and Money in Medieval England (forthcoming), are available in M. R. Allen, 'Silver Production and the Money Supply in England and Wales, 1086-c. 1500', Economic History Review, 63 (2010): 15. For surveys of the coinage under Henry I and King Stephen, see M. Blackburn, 'Coinage and Currency under Henry I: A Review', Anglo-Norman Studies, 13 (1990): 49-81; M. Blackburn, 'Coinage and Currency', in E. King (ed.), The Anarchy of King Stephen's Reign (Oxford: Clarendon, 1994), 145-205.

9 This had been, at least since the late 1970s, the prevalent view. See N. J. Mayhew, 'Frappes de Monnaie et hausse des prix de 1180 à 1220', in J. Day (ed.), Etudes d'histoire monetaire (Lille: Presses Universitaires de Lille, 1984), 159-77; P. D. A. Harvey, 'The English Inflation of 1180-1220', Past \& Present, 61 (1973): 25-9. A challenge to this argument, concerning the period between roughly 1120 and 1190, arose from discussions of possibly significant silver output, and consequent mint output, of the mines near Alston in Cumberland. See, for example, I. Blanchard, 'Lothian and Beyond: The Economy of the "English empire" of David I', in R. H. Britnell and J. Hatcher (eds.), Progress and Problems in Medieval England: Essays in Honour of Edward Miller (Cambridge: Cambridge University Press, 1996), 23-45; P. Claughton, 'Production and Economic Impact: Northern Pennine (English) Silver in the 12th Century', in Proceedings of the 6th International Mining History Congress, September 2003, Akabira City, Hokkaido, Japan (2003), 146-9. Martin Allen, however, has convincingly argued that the monetary impact of this and other English and Welsh mining was rather modest: Allen, 'Silver Production and the Money Supply', 1-18.

10 A. M. Stahl, 'The Sterling Abroad', Haskins Society Journal, 18 (2006): 132-9. See also, for example, J. S. Jensen, 'Two Hoards of Short-Cross Sterlings from Ribe, and English Merchants in Denmark in the Middle of the Thirteenth Century', in Cook and Williams (eds.), Coinage and History, 477-86. On the late thirteenth-century imitations and their quantity, see N. J. Mayhew and D. R. Walker, 'Crockards and Pollards: Imitation and the Problem of Fineness in a Silver Coinage', in Mayhew (ed.), Edwardian Monetary Affairs, 125-46; Allen, 'The Volume of the English Currency', 602-3.

11 See, for example, B. J. Cook, 'The Bezant in Angevin England', Numismatic Chronicle, 159 (1999): $255-75$.

12 J. L. Bolton, 'The English Economy in the Early Thirteenth Century', in S. D. Church (ed.), King John: New Interpretations (Woodbridge: Boydell, 1999), 27-40. On the other hand, James Masschaele has recently argued that the period surrounding and including King John's reign was one of rampant commercialization in spite of King John's monetary problems and excessive exactions: J. Masschaele, 'The English Economy in the Era of Magna Carta', in J. S. Loengard (ed.), Magna Carta and the England of King John (Woodbridge: Boydell, 2010), $151-67$.

13 N. J. Mayhew, 'Modelling Medieval Monetisation', in R. H. Britnell and B. M. S. Campbell (eds.), A Commercialising Economy: England 1086 to c. 1300 (Manchester: Manchester University Press, 1995), 55-77. 
${ }^{14}$ For a comprehensive look at the question of negotiability both in England and Europe up to the seventeenth century, see J. H. Munro, 'The Medieval Origins of the Financial Revolution: Usury, Rentes, and Negotiability', International History Review, 25/5 (2003): 542-56.

15 Mayhew, 'Modelling Medieval Monetisation', 67-8.

${ }^{16}$ For example, see R. C. Stacey, 'Jewish Lending and the Medieval English Economy', in Britnell and Campbell (eds.), A Commercialising Economy, 78-101; P. Brand, 'Jews and the Law in England, 1275-90', English Historical Review, 115 (2000): 1138-58; G. Seabourne, Royal Regulation of Loans and Sales in Medieval England: Monkish Superstition and Civil Tyranny (Woodbridge: Boydell, 2003); R. R. Mundill, 'Changing Fortunes: Edwardian AngloJewry and Their Credit Operations in Late Thirteenth-Century England', Haskins Society Journal, 14 (2003): 83-90; C. D. Briggs, 'Empowered or Marginalized? Rural Women and Credit in Later Thirteenth- and FourteenthCentury England', Continuity and Change, 19 (2004): 13-43; V. Hoyle, 'The Bonds That Bind: Money Lending between Anglo-Jewish and Christian Women in the Plea Rolls of the Exchequer of the Jews, 1218-1280', Journal of Medieval History, 34 (2008): 119-29; A. R. Bell, C. Brooks and T. K. Moore, 'Interest in Medieval Accounts: Examples from England, 1272-1340', History, 94 (2009): 411-33. See also, notably, the collection of essays in P. R. Schofield and N. J. Mayhew (eds.), Credit and Debt in Medieval England, c. 1180-1350 (Oxford: Oxbow Books, 2002).

17 Pamela Nightingale has, however, recently made some progress in quantifying credit from the Statute Merchant and Staple certificates of debt for the period from the 1290s onwards: P. Nightingale, 'Gold, Credit, and Mortality: Distinguishing Deflationary Pressures on the Late Medieval English Economy', Economic History Review, 63/4 (2010): 1081-1104.

${ }_{18}$ See, for example, R. B. Outhwaite, Inflation in Tudor and Early Stuart England (London: Macmillan, 1969); P. H. Ramsey (ed.), The Price Revolution in Sixteenth-century England (London: Methuen, 1971); H. A. Miskimin, 'Population Growth and the Price Revolution in England', Journal of European Economic History, 4 (1975): 179-86; D. O. Flynn, "The "Population Thesis" View of Inflation versus Economic and History' and 'Use and Misuse of the Quantity Theory of Money in Early Modern Historiography' both in E. Van Cauwenberghe and F. Irsigler (eds.), Munzprägung, Geldumlauf und Wechselkurse (Trier: Trierer Historische Forschungen, 1984), 361-83, 383-417; J. A. Goldstone, 'Urbanization and Inflation: Lessons from the English Price Revolution of the Sixteenth and Seventeenth Centuries', American Journal of Sociology, 89 (1984): 1122-60.

${ }_{19}$ M. M. Postan, The Medieval Economy and Society: An Economic History of Britain in the Middle Ages (London: Weidenfeld and Nicolson, 1972), 224-46.

${ }^{20}$ Harvey, 'English Inflation', 3-30.

21 E. Miller and J. Hatcher, Medieval England: Rural Society and Economic Change, 1086-1348 (London: Longman, 1978), 68-9; J. L. Bolton, The Medieval English Economy 1150-1500 (London: Dent, 1980), 76-7.

${ }_{22}$ Mayhew, 'Money and Prices', 121-32.

23 R. C. Palmer, 'The Economic and Cultural Impact of the Origins of Property: 1180-1220', Law and History Review, 3 (1985): 375-96.

${ }^{24}$ A. R. Bridbury, 'Thirteenth-century Prices and the Money Supply', Agricultural History Review, 33 (1985): 1-21; D. L. Farmer, 'Crop Yields, Prices and Wages in Medieval England', Studies in Medieval and Renaissance History, 6 (1983): 139; D. L. Farmer, 'Prices and Wages', in H. E. Hallam (ed.), The Agrarian History of England and Wales, ii, 1042-1348 (Cambridge: Cambridge University Press, 1988), 723-5; J. L. Bolton, 'Inflation, Economics and Politics in Thirteenth-Century England', in P. R. Coss and S. D. Lloyd (eds.), Thirteenth-Century England: Proceedings of the Newcastle upon Tyne Conference, iv (Woodbridge: Boydell, 1992), 4-5.

25 P. Latimer 'Early Thirteenth-century Prices', in Church (ed.), King John, 41-73; P. Latimer, 'Wages in Late Twelfth- and Early Thirteenth-Century England', Haskins Society Journal, 9 (2001 for 1997): 185-205; Latimer, 'Quantity of Money', 637-59; P. Latimer, 'The English Inflation of 1180-1220 Reconsidered', Past E Present, 171 (2001): 3-29.

26 An apposite general warning about the application of mechanistic models to economic history, including those that relied on the quantity of money, was issued in J. Hatcher and M. Bailey, Modelling the Middle Ages; The History and Theory of England's Economic Development (Oxford: Oxford University Press, 2001).

27 Farmer, 'Prices and Wages', 715-817; Farmer, 'Crop Yields', 115-55; D. L. Farmer, 'Some Price Fluctuations in Angevin England', Economic History Review, 2nd Series, 9 (1956-1957): 34-43; D. L. Farmer, 'Some Grain Price Movements in Thirteenth-Century England', Economic History Review, New Series 2 (1957): 207-20; D. L. Farmer, 'Some Livestock Price Movements in Thirteenth-Century England', Economic History Review, New Series 22 (1969): 1-16; T. H. Lloyd, The Movement of Wool Prices in Medieval England (Cambridge: Cambridge University Press, 1973).

${ }^{28}$ D. S. Bachrach, 'Prices, Price Controls, and Market Forces in England under Edward I c. 1294-1307', Haskins Society Journal, 20 (2008): 204-20, especially 207-10.

29 J. L. Bolton, 'What is Money? What is a Money Economy? When did a Money Economy Emerge in Medieval England?', in D. Wood (ed.), Medieval Money Matters (Oxford: Oxbow Books, 2004), 1-15. In the same volume, R. H. Britnell returns to the subject of monetization, tracing the multiplying uses of money up to 1300 : R. H. Britnell, 'Uses of Money in Medieval Britain', in ibid., 16-30. 
30 R. H. Britnell, The Commercialisation of English Society 1000-1500 (Cambridge: Cambridge University Press, 1993); Britnell and Campbell (eds.), A Commercialising Economy. In the latter, note especially Mayhew, 'Modelling Medieval Monetisation', 55-77. Mayhew has more recently revisited this subject in N. J. Mayhew, 'Coinage and Money in England, 1086-c. 1500', in Wood (ed.), Medieval Money Matters, 72-86.

31 For an argument that administrators of estates in the early thirteenth century responded to the opportunities offered by high prices and commerce, but ultimately could not do much more than keep up with inflation, see P. Latimer, 'Estate Management and Inflation: The Honor of Gloucester, 1183-1263', Albion, 34 (2002): $187-212$.

32 The high-value English silver penny was not ideally suited to a mass of low-value transactions, even after price increases over the period had reduced its value. Martin Allen has recently taken a look at the dark side of the monetary system introduced by Henry II and continued by his successors, with its infrequent recoinages leading to periodic deterioration and variability in the coinage: M. R. Allen, 'The English Currency and the Commercialization of England before the Black Death', in Wood (ed.), Medieval Money Matters, 31-50.

33 R. H. Britnell, 'Agriculture, Marketing and Rural Change, 1100-1500', in J. Broad (ed.), A Common Agricultural Heritage? Revising French and British Rural Divergence, Agricultural History Review Supplement Series (Exeter: British Agricultural History Society, 2009), 107-20.

\section{Bibliography}

Allen, M. R., 'Ecclesiastical Mints in Thirteenth Century England', in M. Prestwich, R. H. Britnell and R. Frame (eds.), Thirteenth Century England VIII, Proceedings of the Durham Conference, 1999 (Woodbridge: Boydell, 2001), 97-122.

Allen, M. R., 'The English Currency and the Commercialization of England before the Black Death', in D. Wood (ed.), Medieval Money Matters (Oxford: Oxbow Books, 2004), 31-50.

Allen, M. R., 'The Groats of Edward I', British Numismatic Journal, 74 (2004): 28-38.

Allen, M. R., 'Henry II and the English Coinage', in C. Harper-Bill and N. Vincent (eds.), Henry II: New Interpretations (Woodbridge: Boydell, 2007), 257-77.

Allen, M. R., 'Medieval English Die-Output', British Numismatic Journal, 74 (2004): 29-49.

Allen, M. R., 'The Quantity of Money in England 1180-1247: New Data', British Numismatic Journal, 75 (2005): 44-9.

Allen, M. R., 'Salaries of Mint and Exchange Officials in the Long Cross Recoinage of 1247-50', British Numismatic Journal, 75 (2005): 173-5.

Allen, M. R., 'Silver Production and the Money Supply in England and Wales, 1086-c. 1500', Economic History Review, 63 (2010): 1-18.

Allen, M. R., 'The Volume of the English Currency, 1158-1470', Economic History Review, New Series, 54 (2001): 595-611.

Bachrach, D. S., 'Prices, Price Controls, and Market Forces in England under Edward I c. 1294-1307', Haskins Society Journal, 20 (2008): 204-20.

Bell, A. R., Brooks, C., and Moore, T. K., 'Interest in Medieval Accounts: Examples from England, 1272-1340', History, 94 (2009): 411-33.

Blackburn, M., 'Coinage and Currency', E. King (ed.), The Anarchy of King Stephen's Reign (Oxford: Clarendon, 1994), 145-205.

Blackburn, M., 'Coinage and Currency under Henry I: A Review', Anglo-Norman Studies, 13 (1990): 49-81.

Blanchard, I., 'Lothian and Beyond: The Economy of the "English empire" of David I', in R. H. Britnell and J. Hatcher (eds.), Progress and Problems in Medieval England: Essays in Honour of Edward Miller (Cambridge: Cambridge University Press, 1996), 23-45.

Bolton, J. L., 'The English Economy in the Early Thirteenth Century', in S. D. Church (ed.), King John: New Interpretations (Woodbridge: Boydell, 1999), 27-40.

Bolton, J. L., 'Inflation, Economics and Politics in Thirteenth-Century England', in P. R. Coss and S. D. Lloyd (eds.), Thirteenth-Century England: Proceedings of the Newcastle upon Tyne Conference, iv (Woodbridge: Boydell, 1992), 1-14.

Bolton, J. L., The Medieval English Economy 1150-1500 (London: Dent, 1980).

Bolton, J. L., 'What is Money? What is a Money Economy? When did a money economy emerge in medieval England?', in D. Wood (ed.), Medieval Money Matters (Oxford: Oxbow Books, 2004), 1-15.

Brand, J. D., The English Coinage 1180-1247: Money, Mints and Exchanges (Stroud: Sutton, 1994).

Brand, P., 'Jews and the Law in England, 1275-90', English Historical Review, 115 (2000): 1138-58.

Bridbury, A. R., 'Thirteenth-century Prices and the Money Supply', Agricultural History Review, 33 (1985): 1-21.

Briggs, C. D., 'Empowered or Marginalized? Rural Women and Credit in Later Thirteenth- and FourteenthCentury England', Continuity and Change, 19 (2004): 13-43.

Britnell, R. H., 'Agriculture, Marketing and Rural Change, 1100-1500', in J. Broad (ed.), A Common Agricultural Heritage? Revising French and British Rural Divergence, Agricultural History Review Supplement Series (Exeter: British Agricultural History Society, 2009), 107-20. 
Britnell, R. H., The Commercialisation of English Society 1000-1500 (Cambridge: Cambridge University Press, 1993).

Britnell, R. H., 'Uses of Money in Medieval Britain', in D. Wood (ed.), Medieval Money Matters (Oxford: Oxbow Books, 2004), 16-30.

Britnell, R. H., and Campbell, B. M. S. (eds.), A Commercialising Economy: England 1086 to c. 1300 (Manchester: Manchester University Press, 1995).

Britnell, R. H., and Hatcher, J. (eds.), Progress and Problems in Medieval England: Essays in Honour of Edward Miller (Cambridge: Cambridge University Press, 1996).

Challis, C. E. (ed.), A New History of the Royal Mint (Cambridge: Cambridge University Press, 1992).

Church, S. D. (ed.), King John: New Interpretations (Woodbridge: Boydell, 1999).

Clark, W. N., and Symons, D., 'The Mint of Aylesbury', British Numismatic Journal, 77 (2007): 173-89.

Claughton, P., 'Production and Economic Impact: Northern Pennine (English) Silver in the 12th Century' in Proceedings of the $6^{\text {th }}$ International Mining History Congress, September 2003, Akabira City, Hokkaido, Japan (2003), 146-9.

Cook, B. J., 'The Bezant in Angevin England', Numismatic Chronicle, 159 (1999): 255-75.

Cook, B. J., and Williams, G. (eds.), Coinage and History in the North Sea World, c. AD 500-1250: Essays in Honour of Marion Archibald (Leiden: Brill, 2006).

Coss, P. R., and Lloyd, S. D. (eds.), Thirteenth-Century England: Proceedings of the Newcastle upon Tyne Conference, iv (Woodbridge: Boydell, 1992).

Day, J. (ed.), Etudes d'histoire monetaire (Lille: Presses Universitaires de Lille, 1984).

Eaglen, J. The Abbey and mint of Bury St Edmunds to 1279, British Numismatic Society special publication, 5 (London: Spink, 2006).

Early Medieval Corpus: Single Finds of Coins in the British Isles, 410-1180, http://www-cm.fitzmuseum. cam.ac.uk/emc/emc_intro.html, accessed on 9 Dec, 2010.

Farmer, D. L., 'Crop Yields, Prices and Wages in Medieval England', Studies in Medieval and Renaissance History, 6 (1983): 115-55.

Farmer, D. L., 'Prices and Wages', in H. E. Hallam (ed.), The Agrarian History of England and Wales, ii, 1042-1348 (Cambridge: Cambridge University Press, 1988), 715-817.

Farmer, D. L., 'Some Grain Price Movements in Thirteenth-Century England', Economic History Review, New Series, 2 (1957): 207-20.

Farmer, D. L., 'Some Livestock Price Movements in Thirteenth-Century England', Economic History Review, New Series, 22 (1969): 1-16.

Farmer, D. L., 'Some Price Fluctuations in Angevin England', Economic History Review, 2nd Series, 9 (1956-1957): 34-43.

Flynn, D. O., 'The “Population Thesis" View of Inflation versus Economic and History', in E. Van Cauwenberghe and F. Irsigler (eds.), Munzprägung, Geldumlauf und Wechselkurse (Trier: Trierer Historische Forschungen, 1984), 361-83.

Flynn, D. O., 'Use and Misuse of the Quantity Theory of Money in Early Modern Historiography', in E. Van Cauwenberghe and F. Irsigler (eds.), Munzprägung, Geldumlauf und Wechselkurse (Trier: Trierer Historische Forschungen, 1984), 383-417.

Goldstone, J. A., 'Urbanization and Inflation: Lessons from the English Price Revolution of the Sixteenth and Seventeenth Centuries', American Journal of Sociology, 89 (1984): 1122-60.

Hallam, H. E. (ed.), The Agrarian History of England and Wales, ii, 1042-1348 (Cambridge: Cambridge University Press, 1988).

Harper-Bill, C., and Vincent, N. (eds.), Henry II: New Interpretations (Woodbridge: Boydell, 2007).

Harvey, P. D. A., 'The English Inflation of 1180-1220', Past \& Present, 61 (1973): 25-9.

Hatcher, J., and Bailey, M., Modelling the Middle Ages; The History and Theory of England's Economic Development (Oxford: Oxford University Press, 2001).

Hoyle, V., 'The Bonds That Bind: Money Lending between Anglo-Jewish and Christian Women in the Plea Rolls of the Exchequer of the Jews, 1218-1280', Journal of Medieval History, 34 (2008): 119-29.

Jensen, J. S., 'Two Hoards of Short-Cross Sterlings from Ribe, and English Merchants in Denmark in the Middle of the Thirteenth Century', in B. J. Cook and G. Williams (eds.), Coinage and History in the North Sea World, c. AD 500-1250: Essays in Honour of Marion Archibald (Leiden: Brill, 2006), 477-86.

King, E. (ed.), The Anarchy of King Stephen's Reign (Oxford: Clarendon, 1994).

Latimer, P., 'Early Thirteenth-century Prices', in S. D. Church (ed.), King John: New Interpretations (Woodbridge: Boydell, 1999), 41-73.

Latimer, P., 'The English Inflation of 1180-1220 Reconsidered', Past \& Present, 171 (2001): 3-29.

Latimer, P., 'Estate Management and Inflation': The Honor of Gloucester, 1183-1263', Albion, 34 (2002): $187-212$.

Latimer, P., 'The Quantity of Money in England 1180-1247: A Model', Journal of European Economic History, 32 (2003): 637-59.

Latimer, P., 'Wages in Late Twelfth- and Early Thirteenth-Century England', Haskins Society Journal, 9 (2001) (1997): 185-205. 
Lloyd, T. H., The Movement of Wool Prices in Medieval England (Cambridge: Cambridge University Press, 1973).

Loengard, J. S. (ed.), Magna Carta and the England of King John (Woodbridge: Boydell, 2010).

Masschaele, J., 'The English Economy in the Era of Magna Carta', in J. S. Loengard (ed.), Magna Carta and the England of King John (Woodbridge: Boydell, 2010), 151-67.

Mayhew, N. J., Coinage and Money in England, 1086-c. 1500', in D. Wood (ed.), Medieval Money Matters (Oxford: Oxbow Books, 2004), 72-86.

Mayhew, N. J. (ed.), Edwardian Monetary Affairs (1279-1344), British Archaeological Reports, 36 (Oxford: British Archaeological reports, 1977).

Mayhew, N. J., 'Frappes de Monnaie et hausse des prix de 1180 à 1220', in J. Day (ed.), Etudes d'histoire monetaire (Lille: Presses Universitaires de Lille, 1984), 159-77.

Mayhew, N. J., 'From Regional to Central Minting, 1158-1464', in C. E. Challis (ed.), A New History of the Royal Mint (Cambridge: Cambridge University Press, 1992), 83-178.

Mayhew, N. J., 'Irregularities in the Irish Mint Accounts 1279-84', in N. J. Mayhew and P. Spufford (eds.), Later Medieval Mints: Organisation, Administration and Techniques: The Eighth Oxford Symposium on Coinage and Monetary History, British Archaeological Reports, International Series, 389 (Oxford: British Archaeological Reports, 1988), 87-96.

Mayhew, N. J., 'Modelling Medieval Monetisation', in R. H. Britnell and B. M. S. Campbell (eds.), A Commercialising Economy: England 1086 to c. 1300 (Manchester: Manchester University Press, 1995), 55-77.

Mayhew, N. J., 'Money and Prices in England from Henry II to Edward III', Agricultural History Review, 35 (1987): 121-32.

Mayhew, N. J., and Spufford, P. (eds.), Later Medieval Mints: Organisation, Administration and Techniques: The Eighth Oxford Symposium on Coinage and Monetary History, British Archaeological Reports, International Series, 389 (Oxford: British Archaeological Reports, 1988).

Mayhew, N. J., and Walker, D. R., 'Crockards and Pollards: Imitation and the Problem of Fineness in a Silver Coinage', in N. J. Mayhew (ed.), Edwardian Monetary Affairs (1279-1344), British Archaeological Reports, 36 (Oxford: British Archaeological reports, 1977), 125-46.

Metcalf, D. M., 'A survey of research into the pennies of the first three Edwards (1279-1344) and their continental imitations', in N. J. Mayhew (Ed.), Edwardian Monetary Affairs (1279-1344), British Archaeological Reports, 36 (Oxford: British Archaeological reports, 1977), 1-31.

Miller, E., and Hatcher, J., Medieval England: Rural Society and Economic Change, 1086-1348 (London: Longman, 1978).

Miskimin, H. A., 'Population Growth and the Price Revolution in England', Journal of European Economic History, 4 (1975): 179-86.

Mundill, R. R., 'Changing Fortunes: Edwardian Anglo-Jewry and Their Credit Operations in Late ThirteenthCentury England', Haskins Society Journal, 14 (2003): 83-90.

Munro, J. H., 'The Medieval Origins of the Financial Revolution: Usury, Rentes, and Negotiability', International History Review, 25/5 (2003): 505-62.

Nightingale, P., 'Gold, Credit, and Mortality: Distinguishing Deflationary Pressures on the Late Medieval English Economy', Economic History Review, 63/4 (2010): 1081-104.

Outhwaite, R. B., Inflation in Tudor and Early Stuart England (London: Macmillan, 1969).

Palmer, R. C., 'The Economic and Cultural Impact of the Origins of Property: 1180-1220,' Law and History Review, 3 (1985): 375-96.

Pirenne, H., An Economic and Social History of Medieval Europe, transl. I. E. Glegg (London: Routledge, 1936).

The Portable Antiquities Scheme, Medieval Coin Guide, http://finds.org.uk/medievalcoins, accessed on 9 Dec, 2010.

Postan, M. M., The Medieval Economy and Society: An Economic History of Britain in the Middle Ages (London: Weidenfeld and Nicolson, 1972).

Prestwich, M., Britnell, R. H., and Frame, R. (eds.), Thirteenth Century England VIII, Proceedings of the Durham Conference, 1999 (Woodbridge: Boydell, 2001).

Ramsey, P. H. (ed.), The Price Revolution in Sixteenth-century England (London: Methuen, 1971).

Schofield, P. R., and Mayhew, N. J. (eds.), Credit and Debt in Medieval England, c. 1180-1350 (Oxford: Oxbow Books, 2002).

Seabourne, G., Royal Regulation of Loans and Sales in Medieval England: Monkish Superstition and Civil Tyranny (Woodbridge: Boydell, 2003).

Spufford, P., Money and Its Use in Medieval Europe (Cambridge: Cambridge University Press, 1988).

Stacey, R. C., 'Jewish Lending and the Medieval English Economy', in R. H. Britnell and B. M. S. Campbell (eds.), Commercialising Economy: England 1086 to c. 1300 (Manchester: Manchester University Press, 1995), 78101.

Stack, G., 'A Lost Law of Henry II: The Assize of Oxford and Monetary Reform', Haskins Society Journal, 16 (2006 for 2005): 95-103.

Stahl, A. M., 'The Sterling Abroad', Haskins Society Journal, 18 (2006): 132-9. 
Stewart, I., 'The English and Norman Mints, c. 600-1158', in C. E. Challis (ed.), A New History of the Royal Mint (Cambridge: Cambridge University Press, 1992), 1-82.

Symons, D. J., 'The Moneyers of the Worcester Mint, 1066-1158: Some Thoughts and Comments', in B. J. Cook and G. Williams (eds.), Coinage and History in the North Sea World, c. AD 500-1250: Essays in Honour of Marion Archibald (Leiden: Brill, 2006), 545-88.

Van Cauwenberghe, E., and Irsigler, F. (eds.), Munzprägung, Geldumlauf und Wechselkurse (Trier: Trierer Historische Forschungen, 1984).

Wood, D. (ed.), Medieval Money Matters (Oxford: Oxbow Books, 2004). 